\title{
THE EXRESSION OF ACTUALITY AND TAXIS IN GERMAN AND THEIR UZBEK CORRESPONDENCES
}

\author{
ZOIROV A.A. \\ National University of Uzbekistan, \\ Tashkent, Uzbekistan
}

Article DOI: https://doi.org/10.36713/epra4223

\begin{abstract}
The article deals with the cognitive properties of linguistic means expressing aspectual functions and taxis relations in German and their equivalents in the Uzbek language. Representing the linguistic reflection of reality in time, we are aware of the degree of richness of this linguistic sign. The category of aspectuality and taxis relations in the German language can form various cognitive structures and particular importance for research. Peculiarities of such cognitive structures are more and more revealed when comparing languages.
\end{abstract}

KEY WORDS: category of grammatical aspectuality, grammatical taxis relations, cognitive properties of linguistic means, expressing of facts that occurred at the same time, actions or incidents.

\section{INTRODUCTION}

The different linguistic and non-linguistic regularities emerge as the result of comparative study of the languages.It is possible to determine the essence of all notions by comparison on the basis of the doctrine of I.Cant about the "logical reflexions". The peculiarity of some sign is compared and differed in our logical instrument by induction and deduction and with the help of analogy.

As a result of the investigation of tense relations as a reality, we can understand that this phenomenon is very complicated. It is possible to observe the richness of content of linguistic sign expressing given reality by the conception of linguistic reflection of tense.

The study of cognitive peculiarities of linguistic tools expressing the category of completeness and incompleteness (aspectuality), the relations of sequence or simultaneous "order" (taxis) existed in different languages on the basis of comparison is considered as one of insufficiently known, but actual problems of cognitive grammar.

The linguistic tools expressing the category of aspectuality and taxis relations in German generate different cognitive forms and thereupon they have a special significance for research. The properties of given cognitive forms become more apparent as a result of comparison of languages.

\section{DATA, ANALYSIS AND RESULTS}

It is claimed that the expression of incomplete action in the morphology of traditional German grammar can be precise, recurrent and ordinary. These relations will be covered in the section about the category of aspectuality of the verb. It was explained in the section about the category of tense that the form of present tense of the verb is sometimes precise, and sometimes expresses the ordinary actions. It can be illustrated with following examples ${ }^{1}$ :

Jetzt lese ich ein Buch. (Jetzt bin ich beim Lesen.). - (I'm reading a book now.)

Gewöhnlich lese ich morgens. (Gewöhnlich bin ich morgens beim Lesen.). - I usually read in the morning.

These categories will be mentioned also in the section about the syntax, in particular, about the expression of subject or relations of grammatical adverbial modifier, and it is illustrated with examples similar to foregoing one.

Given relations are investigated together in semantic grammar, and the case in point is space/non-space ${ }^{2}$. In spite of the fact that the

\footnotetext{
${ }^{1}$ Look at the list of literature.

Bondarko A.W. Grundzüge einer
} funktionalen Grammatik. Aspektualität. Zeitliche Lokalisierung. Taxis. Berlin, 2001. / Radčenko O.A. 
linguistic tools expressing space/non-space of tense belong to different grammatical levels, it is important to explain all of them by means of examples and this practice is comfortable for comparison.

It is studied in comparison below, by means of what linguistic tools the incomplete relation is expressed in German and Uzbek.

The indices of tense oft, manchmal, ständig, immer mehr, jeden Abend in German and ko'pincha, ba'zan, doimo, doim, har kecha in Uzbek are used for expressing the incomplete action or recurrent events, for example:

Jede Woche einmal gießt er die Blumen.

$\mathrm{U}$ har haftada bir marta gullarga suv quyadi.

The German verb pflegen, and Uzbek verb odat qilmoq serve for expression of the relation of incompleteness, compare:

Sie pflegte Kuchen zu backen, wenn die Kinder nach Hause kamen.

Uyga bolalari kelganlarida u pishiriq tayorlashni o'ziga odat qilgan.

The German constructions am/beim/im + substantivized infinitive + sein, and Uzbek verbs bayram qilmoq, ko'ngilchog'lik qilmoq, ishsiz bo'lmoq express the duration and incompleteness of an actual process or action, compare:

Wir sind am Feiern.

Bizda bayram. (Bizda ko'ngilchog'lik. Bizda bekorchilik (dam olish).)

The German constructions generating the adverbial verbs sein (im Begriff sein, dabei sein, in etwas begriffen sein), and Uzbek constructions ...da bo'lmoq express the duration of an actual process or action, but their incompleteness, compare:

Ich bin dabei, aus dem Haus zu gehen. I'm going to go out. chiqdim

Men yo'ldaman, endi (hozirgina) uydan

The adverb Gerade and its Uzbek analogue huddi shu damda, ayni damda, hozirgina are used for expression of above-mentioned aspectual relations, compare:

Ich koche gerade. I'm cooking now.

Ayni damda men ovqat pishirmoqdaman.

The indices of time eine Stunde, einen Tag lang, einige Minuten, eine Weile determining the duration of the event, and their Uzbek analogues bir soat davomida, kuni bilan, bir necha daqiqa, bir $\mathrm{oz}$ vaqt are used for the expression of aspectual relations:

Einen ganzen Monat lang weinte sie um ihn...

Das funktional-semantische Feld der Temporalität im Russischen und Deutschen. In: Gladrow, W., Hammel, R. 2001. (Hrsg.): Beiträge zu einer russischdeutschen kontrastiven Grammatik. Frankfurt/Main-Berlin-Bern-New York-Paris-Wien, 169-180. 2001
All month long she mourned for him.

U bir oy davomida ohu-zor bo'lib yig'ladi.

The periphrasis with modal verbs wollen, müssen, sollen and their Uzbek analogues are used for the expression of incompleted action, for example:

Er muss überleben.

Buni u $o^{\prime} z$ boshidan kechrishi lozim. Buni u ko'tara olishi kerak. U tirik qolishi lozim.

The outstanding linguist A.V.Bondarko studied for long the problems of creation of functional-semantic area by relations of grammatical taxis and determination of linguistic tools expressing the constituents of this area. He asserts that the term of taxis was proposed by Roman Osipovich Yakobson. R.O.Yakobson, in his part, used the term "order" proposed by O.Glumfeld. Compare: syntax, parataxis, hipotaxis, taxis. Taxis - order $^{3}$. Taxis informs about the fact unbound with reported fact. Taxis is the relation to the communication of the facts about some realities, events, actions occurred simultaneously. ${ }^{4}$ Taxis belongs not only to time, but also to the relations of convention, instrumentality or modality, namely there are grammatical relations as taxis of conditional subordinate clauses, taxis of instrumental subordinate clauses, taxis of modal (adverbial) subordinate clauses ${ }^{5}$. The relation of taxis in German reveals itself in compound sentences with subordinated clauses of time.

The relations of taxis are observed also in Uzbek subordinated clauses of time. It is very important to analyze the properties of predicate in main clause in this circumstances, because it is required this practice by classification of subordinated clauses. For example, two denotative events occur in the sentence Поезд келди хамки, сухбатимиз тугади. "The train came and our conversation was finished" immediately in series, the succession is changed very quickly, and the event of main clause can be realized only after the event realized in subordinate clause. The place of the word хам is considerable in this expression. But it should be asserted that it will be only if the predicate of main clause is expressed with transitive verb. If it is expressed with intransitive verb, the relations between the denotative events shall be interpreted differently, because the relations of time become turbid and the relation of unhamperedness is appeared. Compare: Поезд келди хамки,

3 Bondarko A.W. Grundzüge einer funktionalen Grammatik. Aspektualität. Zeitliche Lokalisierung. Taxis. Berlin, 2001.

${ }^{4}$ Indicated literature.

${ }^{5}$ Uskenbaev U.Yu., Zoirov A.A. Semantic synonyms and cognitive features of complex sentences with conjunction Indem. (Given to publication) 
сухбатимиз тугади. The train came, and our conversation was finished (relations of time, taxis). Поезд келди хамки, сухбатимиз тугамади. The train came, and our conversation wasn't finished (relation of unhamperedness). ${ }^{6}$

Among consecutive phrases expressing conditional relations, unobtrusive joint phrases are extremely unique in terms of their manifestation and perception. First and foremost, in such discourses there are two types of attitudes, one at a time, and one without barrier. Of course, the basic and consequently unobstructed arguments are those of a barrier, but this is unthinkable because "impediment" means that certain conditions do not prevent the occurrence of the relevant event. The condition is directly involved, not directly, in other words, the condition is present in the same sentence as the presupposition. Unless a conditioned relationship is involved as a baseline, an unrestricted relationship cannot occur. For example, Despite the fact that the young men kept pressing, he did not sit down to eat (Said Ahmad). There is a quote that says, "If you want to sit down," it is normal, common for both the speaker and the listener. The barrier relationship is a violation of this norm, deviation from the normal, exceptional, in other words, if the condition is normal, the barrier is the exception. In this sense, the barrier relationship is more complex and specific than any other relationship. Unobstructed followings are in essence consistent with the state of obstruction. More examples: Although Ahmedbek's pilgrimage was a bit of a relief, he was not happy (E. Yakvalhojaev). Although the time had gone by midnight, Hamza did not shy away (K. Yashin). But no matter how stubborn nature is, they will rebuild the hut again (Said Ahmad). It was still early, but the sun was still burning (H. Sultanov). When an interrupted expression is represented by a verb without interruptions, the condition is strongly expressed, and in spite of such a strong condition the main reaction to the occurrence of the main sentence, namely, the impediment, is increased. This can be seen in the following examples: Even if it does not solve anything, it is interesting to him (A. Mukhtar). Although the rumors were not heard, the marten men understood each other (A. Mukhtar). It was not snowing, but ... it was raining hard (S. Barnoev). Even though Erali does not draw water, he ... shakes horse tracks (Said Ahmad). The content of the barrier may also be subjectively complicated in some discourses. It emphasizes subjective meanings such as rigidity or rigidity of the barrier, temporality. To do this, follow the words, as in the case of the words, and in the main sentence, of course, the same words, emphasizing the rigidity of the obstacle: No matter

${ }^{6}$ Makhmudov N., Nurmonov A. Theoretical grammar of Uzbek (syntax). T., "Uqituvchi”. 1995. P. 125 . how ruthless the shepherd was, there was still a soft heart on the edge of his heart ... (N. Kabul). Even if you do not come, I will come to you (Gulam). This is a man. even if it comes to the sword, he will not sell it (F. Musajopov). Nurse. The child always becomes a child, even though he has a beard and mustache beat (Vegan). In the main sentence it is implied that the content of the barrier can be lost after a certain period of time, without the subjective complication of the content of the barrier. You can see this in the following examples: Even though I had only two younger brothers and sisters in our house, they could not do anything (Gulam). ... Even if the winter was approaching, there was no precipitation in the dry air of the Bukhara region (S. Ainiy) Although the valley was breathing, the circular mountain paths were still steep and dangerous (A. Mukhtar).

There is also a subjective compound complexity in the words that follow consecutive words. But most importantly, they are basically two denotative events. Consequently, their contentsyntactic discrepancies are virtually non-existent. The main sentence is always content free, but the followup is mostly related to its grammatical form and content. Both denotative events are of a real nature. [Mahmudov / Nurmonov 1995. P. 133]

The objective evidence that the syntactic device represents is a governorship. Some authors use the term logic to call it a proposition. Modus represents the relation of an event represented by a syntactic device to the reality of the event and the speaker's response to the event itself. The grammatical categories of the syntactic unit are the grammatical meaning of the syntactic device, and the system of forms that express it, expressed through the variable elements of the syntactic device. The grammatical categories of the sentence also contain grammatical meanings (interrogations, orders, statements, denials, etc.) and grammatical units.

The relation of a story to a particular time, and the system of forms that express it, is a grammatical category of the sentence. This does not mean, however, that the category of the verb is the same as the category of the verb. The category of time can also be expressed outside the verb form. The word "welcome" cannot be used in various forms of the day. I am an employee and there is no verb. But it has a modern meaning. Hence, the modern meaning of the sentence can be expressed through the verb and by the forms it expresses and by the structure of the sentence. The question of paradigms based on the category of time also should not be fixed on the basis of the verb paradigm of the verb. Therefore.T.M. Lomtev distinguishes between physical and grammatical meanings. If the meaning of the physical time is the parts of the real-time flow determined by the time of the speech, the grammatical meaning is a structure divided by a certain length. This structure also includes speech 
momentum, while others represent an event or event that precedes or extends beyond that elongation (not from the moment of speech).

Accordingly, the moment of speech is not a point connecting the past and the future, but a stretch is considered as a certain stretch before it, and the second after it. Not all verb-based statements accept all forms of the verb at all times. In some words, the verb can only occur in its own form. The structure of the speech prevents it from occurring in any other form. He has just come. Thus, while the grammatical category of the verb separates the different forms of the verb, the grammatical category of the sentence separates the different structures of the sentence that allow different verbs to be used in different forms. Whereas members of the verb-grammatical category of the verb are different forms of the same verb, the members of the modern grammatical category of the sentence are different structures that allow the use of different forms of the verb in their composition. Morphological meanings and syntactic meanings are inextricably linked, but are fundamentally different.

It is assumed that the conjunction indem was used earlier for expression of taxis relations, but subsequently the conjunction während appeared from the lexical-semantical connection with the verb währen took this responsibility. For that reason, the compound sentences with subordinated clauses included the conjunction während express the simultaneity of continued action in main and subordinated clauses, for example:

Er schwieg, während sie sprach.

As an analogue of this sentence in Uzbek we can give the following example:

Сайёра гапираётганда Содиқ жим турди.

This subordinated clause is connected with main clause by means of adverbial construction of verb in form -2aH+da, and formed the expression of taxis relation of simultaneity. ${ }^{7}$

The expression of taxis relation of simultaneity is generated in the following similar sentence by means of adverbial construction of verb in form - ган and the adverb пайтда (чоғда):

\section{Содиқ жим турди.}

Сайёра гапираётган пайтда (чоғда)

The use of the conjunction indem in German occurs in a few examples and only in written works before the $\mathrm{X} 1 \mathrm{X}$ century. This conjunction took responsibility only for the expression of taxis relations occurred simultaneously, compare:

7 Look at: Uskenbaev U.Yu. Kontrastive Linguistik. Deutsch-usbekische kontrastive Syntax. Manual for students of Foreign language faculties (philology). - Tashkent: Publishing House of Department of Science and Technologies, 2010. P. 58.
Indem wir uns setzten, ertönte die Klingel.

The notable fact is that the conjunction indem is connected with terminative (resultative, completed) action verbs (according to the terminology of H.Brinkman), and the conjunction während is connected with cursive verbs (expressing the incomplete action). The subordinated clause with the conjunction indem and the verb expressing the process describes the event (Wendung), and the subordinated clause with the conjunction während and the verbs expressing the location in space take part in the expression of duration (Kontinuität).

The conjunction indem, as während, takes part in the relations of comparison and contrasting, compare:

Indem Ferdinand alles tat, seine misslichen Umstände zu verbessern, unterließ Friedrich nichts, seine gute Sache zu verschlimmern. (The example belongs to Schiller and was taken from the textbook of G.N.Eichenbaum "The theoretical grammar of German").

The conjunction indem takes this semantic index by use it with the verbs-predicates expressing the processes and the actions. The conjunction während formed from the verb is used also in combination with the verbs-predicates with the index of quantity (state verbs). Therefore it is not possible to use the conjunction während instead of indem in the first above-mentioned sentence, and it is possible to use it in second sentence, compare:

Indem wir uns setzten, ertönte die Klingel.

*Während wir uns setzten, ertönte die Klingel. (?)

Indem Ferdinand alles tat, seine misslichen Umstände zu verbessern, unterließ Friedrich nichts, seine gute Sache zu verschlimmern.

Während Ferdinand alles tat, seine misslichen Umstände zu verbessern, unterließ Friedrich nichts, seine gute Sache zu verschlimmern.

It is asserted in the dictionaries that the conjunction während is often used, and the conjunction indem expressed the modal, causal and instrumental meanings is archaic and is not used. The conjunction indem used in subordinate clauses of time is considered nowadays archaic. ${ }^{8}$

It is possible to use the conjunction wenn instead of the conjunction während, compare:

Während sie früher immer lustig und frohen Mutes war, ist sie jetzt meist trübsinnig und schweigsam.

Wenn sie früher immer lustig und frohen Mutes war, ist sie jetzt meist trübsinnig und schweigsam.

The relations of comparison and contrast are realized by means of linguistic tools as antonyms

Look at: Duden. Deutsches Universalwörterbuch: 3. Aufl. Mannheim; Wien; Leipzig; Zürich, 1996. 
(there are antonyms also in above-mentioned examples, namely: (verbessern/ verschlimmern, lustig, frohen Mutes/ trübsinnig, schweigsam; früher /jetzt). The conjunction Während takes part in relations of taxis without limit, and it is possible to use it in the expression of relations of simultaneity and succession, for example:

Wie eigentümlich, dachte er, dass ich jetzt in aller Ruhe darüber nachdenken kann, während ich im Sanatorium schlaflose Nächte darüber verbrachte (Mann, 73).

There are the subordinated conjunctions used in subordinated clauses of time as als, wenn, seitdem, nachdem, sobald, sooft, ehe, bevor, währenddessen, seit, bis differentiated according to their functions in actual German, and also other conjunctions. The conjunction indem used as these conjunctions lose its meaning of time and obtained the modal (action), instrumental meanings of comparison and contrast. The conjunction indem is used in the meaning of modality in following examples:

Er reagierte darauf, indem er am 3. April eine Weisung erließ... (Spiegel, 23).

(Ibid., 23)

Er grüßte, indem er den Hut zog.

Er half mir, indem er mir Mut zusprach

It is significant that this subordinated clauses in compound sentences include the meaning of specification, and therefore the content of verbs reagieren, helfen, grüßen is opened wider. V.A.Yamshanov calls these sentences instrumental subordinate clauses, because given sentences have an expression of purposeful action and these sentences include the tool of realization of this action. The objective and tool of action is identified in sentence with the above-mentioned verb grüßen and in the sentence given by V.A.Yamshanova: Er bearbeitete seine Perücke, indem er sie kämmte9 .

If the verb-predicate is used in the main clause for expression of meaning of expressiveness (look at the first above-mentioned sentence) or expresses the casual action of subject in the main clause, it is necessary to use the detailed context for expression of the casual action, for example:

Ich weckte ihn, indem ich die Tür aufmachte.

Ich wollte ihn wecken, indem ich die Tür laut zuschlug.

The modal verb is used for expression of semantic index of result in second of this sentence.

The inanimate substance performs the function of subject as a part of main clause for expression of purposeful action by means of exact tool, for example:

9 Yamshanova V.A. Syntactic function of toolness in modern German: Abstract of . doctorial dissertation.L., 1979.
Adrenalin beeinflusst den Blutzucker, indem er Glykogen abbaut.

The conjunction indem in this sentence takes part in the expression of the meaning of modality and the verb beeinflussen used in the main clause possesses the specializing semantics.

The following sentence has also the meanings of modality, specialization and tools, look at:

Die Grammatik hilft diesen Adressaten, indem sie auf gänzlich neuartige Weise nicht gefestigte oder schlecht verstandene Regeln wiederholt (Kommunikative Grammatik. 4).

The expression of the expression of modality and specializing action is reflected in this example by means of the verb helfen, and the expression of content as "repetition of the badly mastered grammar rules" demonstrates the meaning of tool, look at:

Die Kohle erzeugt Energie, indem sie verbrennt und sich mit dem Sauerstoff der Luft, verbindet.

The word Energie is factitive in this sentence and is used in function of object. The production of this "power of energy" is done in this sentence as a result of an action expressed by means of the verb-predicate erzeugen. The conjunction indem in the subordinated clause takes part in the expression of the meaning of modality, tool and reason.

The subordinated clauses with the conjunction Indem can be used for the definition of discourse verbs expressed the inexact content in the main clause, for example:

Er sagte das, indem seine Stimme einen dröhnenden Klang annahm (Ebner, 232).

Er stellte seine Frage, indem er jedes Wort einzeln betonte.

The subordinated clauses in these sentences have a rich content, many information. The content of main clauses has a few information, but they are independent. The expression of taxis in given examples is secondary, and the modality, tools, definition of action and expression of exact process are of primary importance.

The foreseen, purposeful action is expressed in the following sentence, and is directed to the achievement of a certain result, look at:

Böhme unterbrach ihn, indem er mit beherrschtem Unmut seinen Bleistift auf die Tischplatte warf.

The meaning of tool in this example is harmonized with the content of modality and specification, that is why there is an expression of taxis of simultaneity appeared as a result of using the same grammatical form of verbs-predicates. The subordinated clause is situated before the main clause or in the interval of the main clause. It is natural, because at first something is named and then it is 
expressed or defined. But it is not possible to put the subordinate clause with the conjunction indem before the main clause, look at:

Indem K. Immermann den großen Gedanken von der Unsterblichkeit des Volks aussprach, gab er ihm so einen begrenzten reaktionären Inhalt, in dem er das Volk als eine konservative Kraft auffasste (Lukacs, 243).

It is not possible to change the location of the subordinate clause with the conjunction indem in the given example, because the commenting part here is not a subordinated clause, but the main clause with the word Gedanke illustrating the content of sentence. The example possesses also the meaning of taxis of simultaneity side by side with the meanings of modality and specialization. It is possible to change this sentence in the compound sentence with the conjunction dabei.

\section{CONCLUSION}

By generalizing of analytical materials about the sentences with the conjunction Indem, we can reach a following conclusion: the compound sentences with subordinated clauses included this conjunction can be called the compound sentences with modal subordinated clause includes the symbolic adverb. Because, in the first place, the index of modality in the content of expression taken from many examples of discourse materials is harmonized with the content of taxis of simultaneity in the expression of actions and events in the main and subordinated clauses. In the second place, the instrumentality and its reason are in keeping with the meaning. In the third place, it was observed that the determining and specializing meanings are inseparably linked. Moreover, if these sentences are sometimes used in the main and subordinated clause, they can have a meaning of contrast and create the independent variant of subordinated clauses of time as a competitor of compound sentence with the subordinate clause including während.

It should be asserted that the subordinate sentences with conjunction indem were used in scientific and publicist texts, political and historicalpolitical articles, special professional discourse, office correspondence, author discourse, discourse of characters in belles-letres, with the object of infusion of extensionality to the content of expression and the shade of deep essence to the message, and the disclosure the cognitive properties.

The use of linguistic tools for expression of the category of aspectuality and relations of taxis in the teaching German or Uzbek as foreign language, the study of their cognitive properties in comparison is one of the effective ways for reaching the language competence.

\section{THE LIST OF USED LITERATURE}

1. Bondarko A.W. Grundzüge einer funktionalen Grammatik. Aspektualität.

Lokalisierung. Taxis. Berlin, 2012.

2. Duden 4: Die Grammatik. Dudenredaktion (Hrsg.). 4. völlig neu bearbeitete und erweiterte Aufl. Bd. 4. Mannheim-Leipzig-Wien-Zürich. 1998.

3. Duden. Deutsches Universalwörterbuch: 3.Aufl. Mannheim; Wien; Leipzig; Zürich, 1996.

4. Helbig G., Buscha, J. Deutsche Grammatik. Ein Handbuch für den Ausländerunterricht. Neu bearbeitete Auflage. Leipzig, 2001.

5. Lehmann V. Grammatische Zeitkonzepte und ihre Erklärung. Kognitionswissenschaft 2, 156-170. 1992.

6. Radčenko O.A. Das funktional-semantische Feld der Temporalität im Russischen und Deutschen. In: Gladrow, W., Hammel, R. 2001. (Hrsg.): Beiträge zu einer russischdeutschen kontrastiven Grammatik. Frankfurt/Main-Berlin-Bern-New York-Paris-Wien, 169-180. 2001.

7. Reimann A. Die Verlaufsform im Deutschen. Entwickelt das Deutsche eine Aspektkorrelation? Bamberg, 1998.

8. Makhmudov N., Nurmonov A. Theoretical grammar of Uzbek (syntax). T., "Uqituvchi". 1995.

9. Uskenbaev U.Yu. Kontrastive Linguistik. Deutsch-usbekische kontrastive Syntax. Manual for students of Foreign language faculties (philology). - Tashkent: Publishing House of Department of Science and Technologies, 2010. $121 \mathrm{p}$.

10. Yamshanova V.A. Syntactic function of toolness in modern German: Abstract of doctoral dissertation.L., 1979. 